\title{
Dansylglycine, a fluorescent probe for specific determination of halogenating activity of myeloperoxidase and eosinophil peroxidase
}

\author{
Luiza de Carvalho Bertozo ${ }^{\text {a }}$, Maria Luiza Zeraik ${ }^{\text {b }}$, Valdecir Farias Ximenes ${ }^{\text {a, * }}$ \\ a Department of Chemistry, Faculty of Sciences, UNESP - São Paulo State University, 17033-360, Bauru, São Paulo, Brazil \\ b Department of Chemistry, State University of Londrina (UEL), 86051-990, Londrina, PR, Brazil
}

\section{A R T I C L E I N F O}

\section{Article history:}

Received 21 March 2017

Received in revised form

26 May 2017

Accepted 31 May 2017

Available online 3 June 2017

\section{Keywords:}

Myeloperoxidase

Eosinophil peroxidase

Dansylglycine

Halogenating activity

Hypochlorous acid

Real-time measurement

\begin{abstract}
A B S T R A C T
Myeloperoxidase (MPO) and eosinophil peroxidase (EPO) are enzymes present in neutrophil and eosinophil leukocytes, respectively. Here, we present the development of a sensitive and specific assay for determination of the halogenating enzymatic activity of MPO and EPO based on the electrophilic attack of $\mathrm{HOCl}$ and $\mathrm{HOBr}$ on aromatic ring of dansylglycine (DG). We found that the intrinsic fluorescence of DG was promptly depleted by the action of these acids. In the presence of the enzymes, the fluorescence bleaching was dependent of chloride $\left(\mathrm{Cl}^{-}\right)$and bromide $\left(\mathrm{Br}^{-}\right)$, which makes the assay able to distinguish the halogenating from the peroxidase activity. A linear correlation was obtained between the hydrogen peroxide $\left(\mathrm{H}_{2} \mathrm{O}_{2}\right)$ concentration and the fluorescent decay. Similarly, the enzyme activity was measured by keeping constant $\mathrm{H}_{2} \mathrm{O}_{2}$. The method was applied for studding MPO/EPO specific inhibitors as 5-fluortryptamine (reversible inhibitor) and 4-hydroxybenzhydrazide (irreversible inhibitor). Differently of the taurine chloramine/3,3',5,5'-tetramethylbenzidine assay, which is among the most used technique, the dansylglycine assay was able to differentiate these inhibitors based on their kinetic behavior. In conclusion, this assay can differentiate the peroxidase and halogenating activity of MPO and EPO. Moreover, the method is adequate for real-time measurement of the production of $\mathrm{HOCl}$ and $\mathrm{HOBr}$.
\end{abstract}

(C) 2017 Elsevier Inc. All rights reserved.

\section{Introduction}

Myeloperoxidase (MPO) is an enzyme abundantly present in the azurophilic granules of neutrophils, the predominant leukocyte in the circulation [1]. MPO is engaged in the innate immune defense, acting against invading pathogens by catalyzing the oxidation of chloride $\left(\mathrm{Cl}^{-}\right)$to hypochlorous acid $(\mathrm{HOCl})$. This halogenating and oxidizing agent is a potent microbicidal compound, which is released into the phagosome and/or into the extracellular medium when neutrophils are challenged by bacteria, fungi, etc [1,2]. Similarly, eosinophilic leukocytes are endowed with the structurally related enzyme eosinophil peroxidase (EPO), which is devoted to catalyze the oxidation of bromide $\left(\mathrm{Br}^{-}\right)$to hypobromous acid (HOBr) [3]. Differently of neutrophilia, which are involved in several inflammatory processes, eosinophilia is typically related to the pathogenesis of asthma, allergic and parasitic diseases [4].

\footnotetext{
* Corresponding author. Department of Chemistry, Faculty of Science, São Paulo State University (UNESP), Av. Eng. Luiz Edmundo Carrijo Coube, 14-01, CEP 17033360, Bauru, São Paulo, Brazil.

E-mail address: vfximenes@fc.unesp.br (V.F. Ximenes).
}

The preceding paragraph describes an important and exclusive feature of MPO, because differently from others peroxidases, this enzyme is the unique able to catalyze efficiently at $\mathrm{pH} 7.0$ the oxidation of $\mathrm{Cl}^{-}$to $\mathrm{HOCl}$ [5]. It is noteworthy that peroxidases are usually described as "promiscuous" enzymes in the sense of their lack of substrate specificity [6]. This is not different for MPO, which acts by two main pathways. One of them is the peroxidase cycle, a two-step oxidation mechanism involving the transient redox active forms compound I and II (MPO-I and MPO-II), which are responsible by the one-electron oxidation of a myriad of phenols and aromatic amines; the other mechanism of catalytic action is the chlorinating cycle, responsible by the two-electron oxidation of $\mathrm{Cl}^{-}$, $\mathrm{Br}^{-}$and $\mathrm{SCN}^{-}$to the respective $\mathrm{HOCl}, \mathrm{HOBr}$ and $\mathrm{HOSCN}[5,7,8]$. The following chemical reactions describe the peroxidase (1-3) and chlorinating ( 1 and 4 ) catalytic cycles of MPO:

$$
\mathrm{MPO}+\mathrm{H}_{2} \mathrm{O}_{2} \rightarrow \mathrm{MPO}(\mathrm{I})+\mathrm{H}_{2} \mathrm{O}
$$

$M P O(I)+A H \rightarrow M P O(I I)+A^{\mathrm{o}}$ 
$\mathrm{MPO}(\mathrm{II})+\mathrm{AH} \rightarrow \mathrm{MPO}+A^{\mathrm{O}}$

$\mathrm{MPO}(\mathrm{I})+\mathrm{Cl}^{-} / \mathrm{Br}^{-} / \mathrm{SCN}^{-} \rightarrow \mathrm{MPO}+\mathrm{HOCl} / \mathrm{HOBr} / \mathrm{HOSCN}$

Where $\mathrm{AH}$ and $\mathrm{A}$ represent phenols and aromatic amines in its reduced and oxidized forms, respectively.

Besides their roles in the innate immune defense, MPO and EPO are also involved in deleterious processes related to inflammatory, allergic and degenerative diseases [9-12]. This is due to the capacity of $\mathrm{HOCl}$ and $\mathrm{HOBr}$ as oxidants of several cell constituents leading to their degradation and loss of function [13]. For this reason, to inhibit the halogenating activity of these enzymes is a current hot topic in biomedical research [14,15].

To study the inhibition of these enzymes is necessary analytical procedures able to differentiate peroxidase and halogenating activities of MPO and EPO. In this regard, one of the first substrate used for this propose was the $\beta$-diketone, monochlorodimedon. The enol form of monochlorodimedon reacts with $\mathrm{HOCI}$ to produce dichlorodimedon and the reaction can be monitored by the absorbance loss at $290 \mathrm{~nm}$ [16]. However, this method lacks specificity, since the enol form is also able to react through peroxidase pathway [17]. Other widely used method for measurement of chlorinating activity of MPO is a two steps procedure by which the formation of $\mathrm{HOCl}$ is captured by taurine leading to the formation of taurine chloramine. This is a mild and stable oxidizing agent whose concentration is measured in the second step of the method by the oxidation of the aromatic thiol, 5-thio-2-nitrobenzoic acid (TNB) [17] or 3,3',5,5'-tetramethylbenzidine (TMB) at acid pH [18]. These methods are selective to the chlorinating activity of MPO. Particularly, they are largely used for determination of $\mathrm{HOCl}$ produced by purified MPO and isolated neutrophil [18]. However, they are not adequate for determination of intracellular production of $\mathrm{HOCl}$, since taurine chloramine could be depleted by reacting with sulfhydryl moieties inside the cells. Moreover, the chromogenic substrates TNB and TMB are susceptible to oxidation by others reactive oxygen species. Therefore, fluorescent probes have been developed for specific intracellular determination of $\mathrm{HOCl}$, which have potential application in flow cytometry-based assays and imaging studies. They are based on xanthene dyes, which became fluorescent upon reacting with $\mathrm{HOCl}$. Among them, 2-[6-(4'-hydroxy) phenoxy-3H-xanthen-3-on-9-yl]benzoic acid (HPF) and 2-[6-( $4^{\prime}-$ amino)phenoxy-3H-xanthen-3-on-9-yl]benzoic acid (APF) have been proposed. The authors showed that both probes can be oxidized by hydroxyl radical, but only $\mathrm{HOCl}$ is able to react with APF [19]. More recently, AFP was used to detect the intracellular production of $\mathrm{HOCl}$ in neutrophils [20] and $\mathrm{HOBr}$ produced by eosinophils using flow cytometry [21]. Another successful method is based on HOCl-promoted cyclization of rhodaminethiosemicarbazides to rhodamine-oxadiazoles. In this technique, the probe shows an emission at $473 \mathrm{~nm}$, which is typical of coumarin moiety. Then, upon addition of $\mathrm{HOCl}$, a cyclization takes place and through resonance energy transfer, the probe starts to emit as a rhodamine at $594 \mathrm{~nm}$ [22]. Considering the importance of selective determination of $\mathrm{HOCl}$ and $\mathrm{HOBr}$, we had worked in a new analytical approach for determination of halogenating activity of MPO/EPO. Here, the selectivity was based on the electrophilic reactivity of these acids with aromatic compounds. We will show that the fluorescent probe dansylglycine can be used to distinguish the peroxidase and halogenating activities of MPO and EPO.

\section{Materials and methods}

\section{Chemicals and reagents}

Dansylglycine, taurine, 3,3',5,5'-tetramethylbenzidine (TMB), 5fluorotryptamine, 4-hydroxybenzhydrazide, horseradish peroxidase (HRP) and catalase were purchased from Sigma-Aldrich Chemical Co. (St. Louis, MO, USA). MPO and EPO (EC 1.11.1.7) were purchased from Planta Natural Products (Vienna, Austria) and their concentrations were determined from their absorption at $430 \mathrm{~nm}$ $\left(\varepsilon=89,000 \mathrm{~mol}^{-1} \mathrm{~L} \mathrm{~cm}{ }^{-1}\right.$ per heme) and $413 \mathrm{~nm}$ $\left(\varepsilon=110,000 \mathrm{~mol}^{-1} \mathrm{~L} \mathrm{~cm}^{-1}\right)$ for MPO and EPO, respectively $[23,24]$. Hydrogen peroxide $\left(\mathrm{H}_{2} \mathrm{O}_{2}\right)$ was prepared by diluting a $30 \%$ stock solution purchased from Peroxides do Brasil (Sao Paulo, SP, Brazil), and its concentration was calculated using its absorption at $240 \mathrm{~nm}$ $\left(\varepsilon=43.6 \mathrm{~mol}^{-1} \mathrm{~L} \mathrm{~cm}^{-1}\right.$ ) [25]. $\mathrm{HOCl}$ was prepared by diluting a $5 \%$ stock solution and the concentration was determined spectrophotometrically after dilution in $0.01 \mathrm{~mol} \mathrm{~L}^{-1} \mathrm{NaOH}, \mathrm{pH} 12$ at $292 \mathrm{~nm}$ ( $\varepsilon=350 \mathrm{~mol}^{-1} \mathrm{~L} \mathrm{~cm}^{-1}$ ) [26]. HOBr was prepared by combining $100 \mathrm{mmol} \mathrm{L}^{-1} \mathrm{HOCl}$ and $200 \mathrm{mmol} \mathrm{L}^{-1} \mathrm{NaBr}$ in water [27]. TMB solution (14 $\mathrm{mmol} \mathrm{L}^{-1}$ ) was prepared by dissolving the adequate mass in 1:1 dimethylformamide and $400 \mathrm{mmol} \mathrm{L}^{-1}$ acetic acid. To this solution, $100 \mu \mathrm{mol} \mathrm{L}{ }^{-1}$ potassium iodide was added and the reagent immediately used [28]. Stock solution of dansylglycine $\left(2.5 \mathrm{mmol} \mathrm{L}^{-1}\right)$ was prepared by dissolving the adequate mass in $0.01 \mathrm{~mol} \mathrm{~L}^{-1}$ hydrochloric acid. Phosphate buffered saline (PBS) was prepared as follow: phosphate $10 \mathrm{mmol} \mathrm{L}^{-1}, \mathrm{NaCl} 138 \mathrm{mmol} \mathrm{L}^{-1}, \mathrm{KCl}$ $2.7 \mathrm{mmol} \mathrm{L}^{-1}$ and the $\mathrm{pH}$ adjusted to 7.4. All solutions were prepared with water purified by a Milli-Q system (Millipore, Bedford, MA, USA). All reagents used for buffer preparation were of analytical grade.

\section{HOCl-promoted halogenation of dansylglycine}

The study of $\mathrm{HOCl}$-promoted halogenation of dansylglycine was performed by stopped-flow and conventional spectrofluorimetry. The fast-kinetic experiments were performed using a single-mixing stopped-flow system equipped with a high intensity LED source $(360 \mathrm{~nm})$ and cut-off filter (475 nm) (SX20/LED Stopped-Flow System, Applied Photophysics, UK). The relative rate constants were obtained by fitting the fluorescence bleaching to a single exponential decay equation, as follows:

$F=F_{0} * e^{-k^{*} t}$

Where $F$ is the fluorescence at any time and $F_{0}$ is the initial fluorescence. The reaction mixture was composed of $50 \mu \mathrm{mol} \mathrm{L} \mathrm{L}^{-1}$ dansylglycine, $100 \mu \mathrm{mol} \mathrm{L}^{-1} \mathrm{HOCl}$ and increasing concentrations of $\mathrm{Br}^{-}$in PBS, pH 7.4 at $25^{\circ} \mathrm{C}$.

The consumption of dansylglycine was also measured using conventional spectrofluorimetry. In this case, the experiments were adapted to microplate assay using a black 96-well flat bottom microplate. The multi-detector microplate reader (Synergy 2 MultiMode, BioTek, USA) was set for spectral scanning analysis (excitation at $340 \mathrm{~nm}$ and emission in the range of $400-650 \mathrm{~nm}$ ) or endpoint reading (excitation at $340 \mathrm{~nm}$ and emission at $525 \mathrm{~nm}$ ). Otherwise stated, the reaction medium was constituted of $50 \mu \mathrm{mol} \mathrm{L}{ }^{-1}$ dansylglycine, $1 \mathrm{mmol} \mathrm{L}^{-1} \mathrm{Br}^{-}$and increasing concentrations of $\mathrm{HOCl}$ in PBS, pH 7.4 at $25{ }^{\circ} \mathrm{C}$. The reactions were initiated by adding $\mathrm{HOCl}$ and incubated for $5 \mathrm{~min}$. The final reaction volume was $250 \mu \mathrm{L}$. 


\section{MPO and EPO catalyzed bromination of dansylglycine}

Unless otherwise stated, the reaction medium was composed of $20 \mathrm{nmol} \mathrm{L^{-1 }}$ MPO or EPO, $50 \mu \mathrm{mol} \mathrm{L}^{-1}$ dansylglycine, $100 \mu \mathrm{mol} \mathrm{L}^{-1} \mathrm{H}_{2} \mathrm{O}_{2}$, and $10 \mathrm{mmol} \mathrm{L}^{-1} \mathrm{Br}^{-}$in PBS, pH 7.4 at $25^{\circ} \mathrm{C}$. For the endpoint experiments the fluorescence was measured $30 \mathrm{~min}$ after the addition of $\mathrm{H}_{2} \mathrm{O}_{2}$. The final reaction volume was $250 \mu \mathrm{L}$ and the microplate reader was set at $340 / 525 \mathrm{~nm}$. For determination of MPO activity, the enzyme concentration was reduced to 4-20 nmol L $\mathrm{L}^{-1}$ and the time-dependent fluorescence bleaching measured in the linear part of the curve. The microplate reader was set to acquire the fluorescence intensity at $1 \mathrm{~min}$ intervals. The calibration curves were raised and the limit of detection (LOD) calculated according to the formula: $\mathrm{LOD}=3.3 \mathrm{Sy} / \mathrm{S}$. Where $S y$ is the standard deviation of the response ( $y$-intercepts of the regression line) and $S$ is the slope of the calibration curve.

\section{MPO chlorination activity by taurine/TMB assay}

The chlorination activity of MPO was determined based on the reaction of $\mathrm{HOCl}$ with taurine to produce taurine chloramine and subsequent determination of this oxidant using the TMB reagent [28]. The reaction medium was composed of 20 or $80 \mathrm{nmol} \mathrm{L}^{-1}$ MPO, $100 \mu \mathrm{mol} \mathrm{L}^{-1} \mathrm{H}_{2} \mathrm{O}_{2}, 10 \mathrm{mmol} \mathrm{L}{ }^{-1}$ taurine in PBS, pH 7.4 at $25^{\circ} \mathrm{C}$. The final volume was $200 \mu \mathrm{L}$. The reactions were initiated by the addition of $\mathrm{H}_{2} \mathrm{O}_{2}$ and incubated for $30 \mathrm{~min}$. Then, $0.1 \mathrm{mg} \mathrm{mL}^{-1}$ catalase was added to stop the reaction, and after $5 \mathrm{~min}, 50 \mu \mathrm{L}$ of the TMB reagent was added and the absorbance measured at $650 \mathrm{~nm}$.

\section{HPLC and mass spectrometry}

The reaction medium was composed of $1 \mathrm{mmol} \mathrm{L}^{-1}$ dansylglycine, $1 \mathrm{mmol} \mathrm{L}{ }^{-1} \mathrm{HOCl}, 10 \mathrm{mmol} \mathrm{L}^{-1} \mathrm{Br}^{-}$in PBS, pH 7.4 at $25^{\circ} \mathrm{C}$. The reactions were conducted for $5 \mathrm{~min}$. The consumption of dansylglycine and formation of products was chromatographically evaluated by HPLC. The analyses were carried out isocratically on a Luna C18 reversed-phase column ( $250 \mathrm{~mm} \times 4.6 \mathrm{~mm}, 4 \mu \mathrm{m})$, using $0.1 \%$ formic acid in water and $0.1 \%$ formic acid in acetonitrile (95:5, v:v) as mobile phase and flow rate of $1.0 \mathrm{~mL} \mathrm{~min}^{-1}$ (Jasco, Easton, MD, USA). The high resolution mass spectra (HRMS) analysis were obtained in a micrOTOF-Q II-Bruker spectrometer (Bruker, Massachusetts, EUA).

\section{Electrochemical studies}

The $\mathrm{H}_{2} \mathrm{O}_{2}$ consumption was monitored amperometrically with a $\mathrm{H}_{2} \mathrm{O}_{2}$-selective electrode coupled to a TBR4100 Free Radical Analyzer (World Precision Instruments, Sarasota, FL, USA). Two reaction system were studied: (1) taurine $10 \mathrm{mmol} \mathrm{L}-1, \mathrm{H}_{2} \mathrm{O}_{2}$ $100 \mu \mathrm{mol} \mathrm{L}{ }^{-1}$, MPO $20 \mathrm{nmol} \mathrm{L}^{-1}$ in PBS, pH 7.4 at $25{ }^{\circ} \mathrm{C}$ or (2) dansylglycine $50 \mu \mathrm{mol} \mathrm{L}{ }^{-1}, \mathrm{Br}^{-} 10 \mathrm{mmol} \mathrm{L}{ }^{-1}, \mathrm{H}_{2} \mathrm{O}_{2} 100 \mu \mathrm{mol} \mathrm{L}^{-1}$, MPO $20 \mathrm{nmol} \mathrm{L}^{-1}$ in PBS, pH 7.4 at $25^{\circ} \mathrm{C}$. The reactions were triggered by $\mathrm{H}_{2} \mathrm{O}_{2}$.

\section{Results and discussion}

\section{Reaction with $\mathrm{HOCl}$ and the effect of $\mathrm{Br}^{-}$}

Dansylglycine is a fluorescent compound used as a site 2 specific ligand of serum albumin [29]. Recently, we demonstrated that dansylglycine reacts promptly with $\mathrm{HOBr}$. In addition, we showed that its apparent second-order rate constant with $\mathrm{HOBr}$ $\left(7.3 \times 10^{6} \mathrm{~mol}^{-1} \mathrm{~L} \mathrm{~s}^{-1}\right)$ was three order of magnitude higher compared to $\mathrm{HOCl}\left(5.2 \times 10^{2} \mathrm{~mol}^{-1} \mathrm{~L} \mathrm{~s}^{-1}\right)$ [30]. Considering that $\mathrm{HOCl}\left(\mathrm{E}^{\circ}=1.28 \mathrm{~V}\right)$ is a stronger oxidant compared to $\mathrm{HOBr}$
$\left(\mathrm{E}^{\circ}=1.13 \mathrm{~V}\right)[31]$; the higher reactivity of $\mathrm{HOBr}$ is an indication that the susceptibility to electrophilic attack, but not to oxidation, must be the major reactional feature of dansylglycine in the context of its reaction with these acids. In agreement, the higher electrophilicity of $\mathrm{HOBr}$ compared to $\mathrm{HOCl}$ was also demonstrated for others reactions with aromatic compounds as salicylic acid, anisole, acetophenone, uracil and uridine [30]. These finding and the absence free anilinic, enolic or phenolic groups in the molecular structure of dansylglycine leaded us to consider that this fluorescent probe would not be susceptible to direct peroxidase catalytic cycle of MPO. On the other hand, it would be susceptible to the products of the halogenating activity of MPO.

Although the reactivity of dansylglycine with $\mathrm{HOBr}$ is significantly higher compared to $\mathrm{HOCl}$, the last is the main halogenating species produced physiologically through the catalytic action of MPO $[1,2,5]$. Therefore, the first step in this study was to improve the reactivity of dansylglycine with $\mathrm{HOCl}$, which was accomplished by adding the $\mathrm{Br}^{-}$into the reaction medium. The results in Fig. 1a show the effect of addition of $\mathrm{Br}^{-}$in the rate of fluorescence bleaching of dansylglycine provoked by $\mathrm{HOCl}$. From these experiments, the relative rate constants were measured and the following values were obtained: $0.148 \mathrm{~s}^{-1}\left(\mathrm{Br}^{-} 0 \mu \mathrm{mol}^{-1} \mathrm{~L}\right), 0.396 \mathrm{~s}^{-1}\left(\mathrm{Br}^{-}\right.$ $\left.12.5 \mu \mathrm{mol}^{-1} \mathrm{~L}\right), 0.604 \mathrm{~s}^{-1}\left(\mathrm{Br}^{-} 25 \mu \mathrm{mol}^{-1} \mathrm{~L}\right), 1.13 \mathrm{~s}^{-1}\left(\mathrm{Br}^{-}\right.$ $\left.50 \mu \mathrm{mol}^{-1} \mathrm{~L}\right)$ and $2.47 \mathrm{~s}^{-1}\left(\mathrm{Br}^{-} 100 \mu \mathrm{mol}^{-1} \mathrm{~L}\right)$. These results confirmed our expectation and can be explained taking into account the formation of $\mathrm{HOBr}$ by the reaction between $\mathrm{Br}^{-}$and $\mathrm{HOCl}$. These results were obtained using fast kinetic experiments, therefore not adequate for conventional microplate-based assays. Thus, we also measured the effect of $\mathrm{Br}^{-}$in a higher time scale experiment and adapted to microplates (endpoint experiments). The results depicted in Fig. 1b shows the fluorescence bleaching measured after five minutes and the effect of addition of $\mathrm{Br}^{-}$. A significant increase in the consumption of dansylglycine was obtained using $1.0 \mathrm{mmol} \mathrm{L}^{-1}$ of $\mathrm{Br}^{-}$, a concentration that was used in

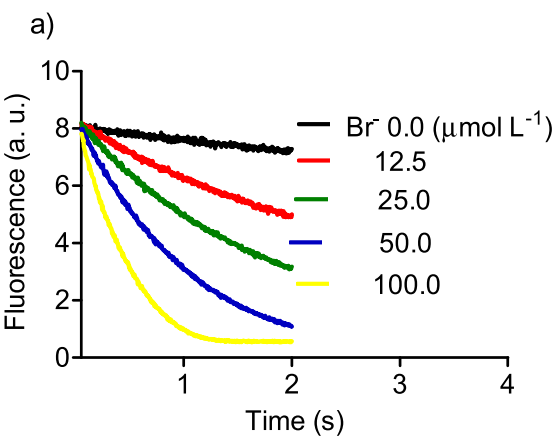

b)

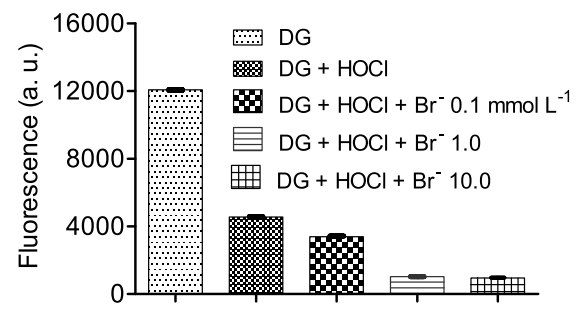

Fig. 1. Reactivity of dansylglycine (DG) with $\mathrm{HOCl}$ and the effect of $\mathrm{Br}^{-}$. (a) Kinetic profile of dansylglycine consumption. The reaction mixture was composed of $50 \mu \mathrm{mol} \mathrm{L}^{-1}$ dansylglycine, $100 \mu \mathrm{mol} \mathrm{L} \mathrm{L}^{-1} \mathrm{HOCl}$ and increasing concentrations of $\mathrm{Br}^{-}$in PBS, pH 7.4 at $25^{\circ} \mathrm{C}$. The stopped-flow system was set as follows: excitation $340 \mathrm{~nm}$ LED and emission $475 \mathrm{~nm}$ cut-off filter. (b) Effect of $\mathrm{Br}^{-}$. In this case the remaining fluorescence was measured after 5 min of the addition of $\mathrm{HOCl}$ (endpoint experiment). The results are the mean and SD of three experiments. 
the subsequent experiments with $\mathrm{HOCl}$.

In the sequence, we evaluated how sensitive was the fluorescence bleaching of dansylglycine regarding the concentration of $\mathrm{HOCl}$. In these studies, $\mathrm{HOCl}$ was varied from 0 to $100 \mu \mathrm{mol} \mathrm{L}^{-1}$, a range typically found in studies using MPO and $\mathrm{HOCl}$ [32-34]. The results depicted in Fig. 2 show the excellent correlation between the $\mathrm{HOCl}$ concentration and fluorescence bleaching of dansylglycine. The data were plotted as the variation of fluorescence (FLuo$\mathrm{r}_{\text {Initial }}-$ Fluor $\left._{\text {final }}\right)$ as a function of concentration of $\mathrm{HOCl}$. The detection limit was $2.3 \mu \mathrm{M}$ (measured as $\mathrm{LOD}=3.3 \mathrm{Sy} / \mathrm{S}$ ).

\section{Identification of the reaction products}

As we have stated above, the chemical principle for the application of dansylglycine as a potential substrate for measurement of halogenating activity of MPO and EPO is based on its susceptibility to electrophilic attack of $\mathrm{HOBr} / \mathrm{HOCl}$ (Fig. 3). This hypothesis was confirmed by measuring the exact mass of the reaction products. The mass spectrum of the reaction product confirmed the formation of monobrominated derivative of dansylglycine, as concluded by comparison with the reactant mass spectrum, examination of the exact mass of the molecular ion and by the expected isotopic distribution due to the presence of bromine atom ([M-H]: 384.9933 (51\%) and 386.9895 (49\%) (Supplementary Material).

\section{Reaction of dansylglycine with $\mathrm{MPO} / \mathrm{H}_{2} \mathrm{O}_{2} / \mathrm{Cl}^{-} / \mathrm{Br}^{-}$}

So far, we have demonstrated the susceptibility of dansylglycine to electrophilic attack of $\mathrm{HOCl} / \mathrm{Br}^{-}$. The next step was to study the efficiency of the reaction using MPO as the source of HOCl. Initially, the role of $\mathrm{Br}^{-}$in the reaction efficiency was evaluated. In these experiments, the concentrations of the components were MPO $\left(20 \mathrm{nmol} \mathrm{L}^{-1}\right), \mathrm{H}_{2} \mathrm{O}_{2}\left(100 \mu \mathrm{mol} \mathrm{L}^{-1}\right), \mathrm{Cl}^{-}\left(\mathrm{PBS}, 140 \mathrm{mmol} \mathrm{L}{ }^{-1}\right)$ and
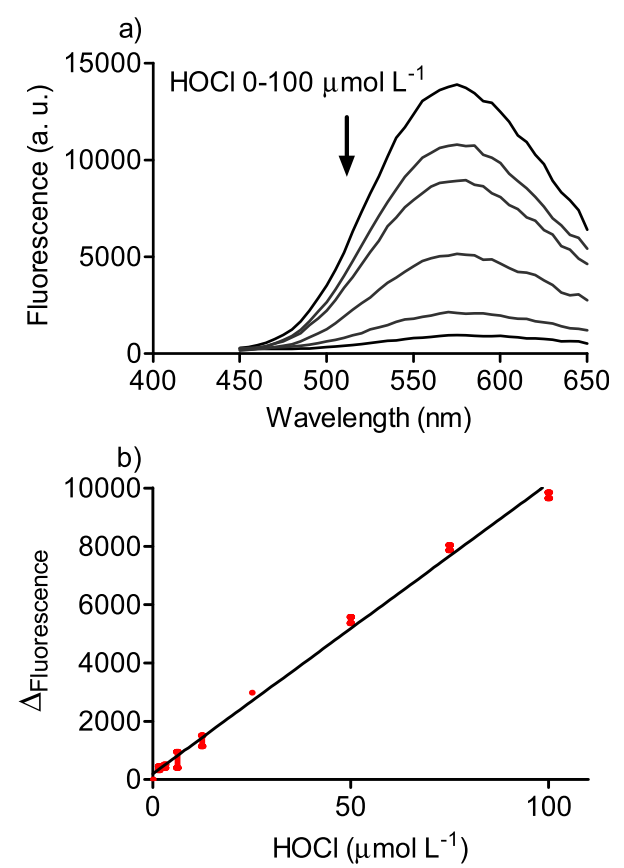

Fig. 2. Determination of $\mathrm{HOCl}$ by its reactivity with dansylglycine. (a) Fluorescence spectra of dansylglycine measured 5 min after addition of $\operatorname{HOCl}(0,12.5,25.0,50.0,75.0$ and $100 \mu \mathrm{mol} \mathrm{L}^{-1}$ ). (b) Analytical curve $\Delta_{\text {fluorescence }}$ versus $\mathrm{HOCl}$ concentration. The reaction mixture was composed of $50 \mu \mathrm{mol} \mathrm{L}^{-1}$ dansylglycine, $1 \mathrm{mmol} \mathrm{L}^{-1} \mathrm{Br}^{-}$and increasing concentrations of $\mathrm{HOCl}$ in $\mathrm{PBS}, \mathrm{pH} 7.4$ at $25^{\circ} \mathrm{C}$. The final reaction volume was $250 \mu \mathrm{L}$ and the microplate reader was set at 340/550. The results are the mean and $\mathrm{SD}$ of three experiments, $\mathrm{r}^{2}=0.9944, L O D=2.3 \mu \mathrm{mol} \mathrm{L}^{-1}$.
$\mathrm{Br}^{-}$varied. The results depicted in Fig. 4a show that dansylglycine also reacted with the $\mathrm{HOCl}$ generated by the enzymatic system in the presence of $\mathrm{Br}^{-}$. Compared to the experiments with pure $\mathrm{HOCl} /$ $\mathrm{Br}^{-}$, the reaction rate was lower; therefore, the consumption of<smiles>CN(C)c1cccc2c(S(=O)(=O)NCC(=O)O)cccc12</smiles>

Fluorescent<smiles>Cc1cccc2c(S(=O)(=O)NCC(=O)O)cccc12</smiles>

Non-fluorescent
Fig. 3. Chemical equation for the monobromination of dansylglycine.
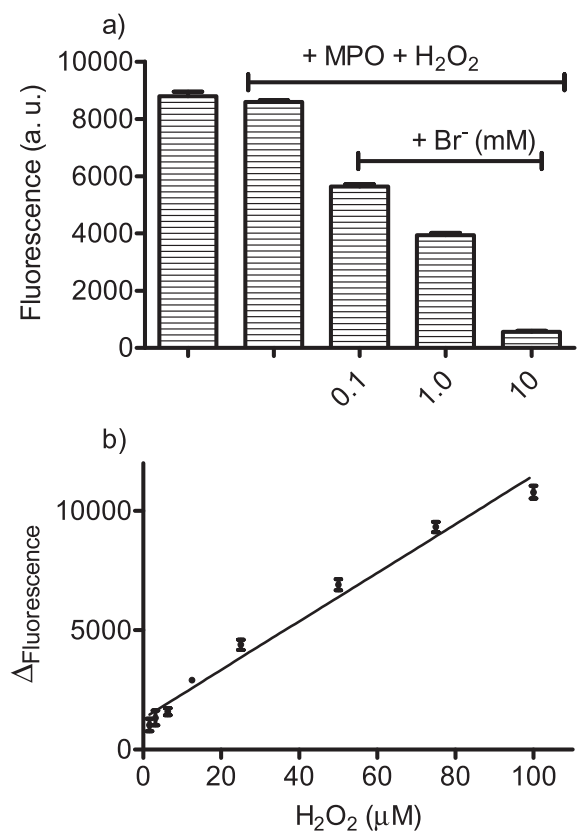

c)

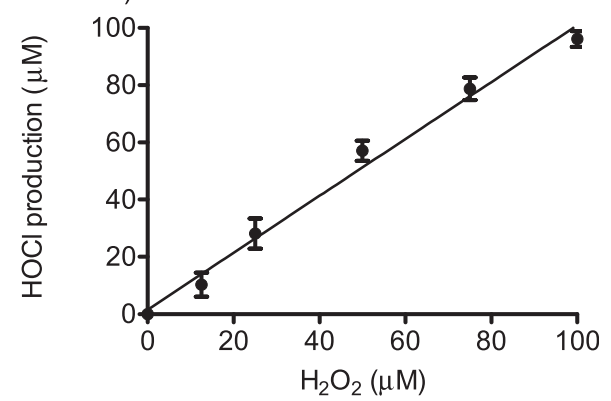

Fig. 4. Determination of $\mathrm{HOCl}$ produced by $\mathrm{MPO} / \mathrm{H}_{2} \mathrm{O}_{2}$ using the dansylglycine method. (a) Dansylglycine fluorescence measured 30 min after addition of $\mathrm{H}_{2} \mathrm{O}_{2}$ in the presence or absence of $\mathrm{Br}^{-}$. The reaction mixture was composed of $20 \mathrm{nmol} \mathrm{L}^{-1} \mathrm{MPO}$, $50 \mu \mathrm{mol} \mathrm{L}{ }^{-1}$ dansylglycine, $100 \mu \mathrm{mol} \mathrm{L}^{-1} \mathrm{H}_{2} \mathrm{O}_{2}$ and the indicated concentration of $\mathrm{Br}^{-}$ in PBS, pH 7.4 at $25{ }^{\circ} \mathrm{C}$ (b) Analytical curve $\Delta_{\text {fluorescence }}$ versus $\mathrm{H}_{2} \mathrm{O}_{2}$ concentration. The reaction mixture was composed of $20 \mathrm{nmol} \mathrm{L}{ }^{-1} \mathrm{MPO}, 50 \mu \mathrm{mol} \mathrm{L}^{-1}$ dansylglycine, $10 \mathrm{mmol} \mathrm{L}^{-1} \mathrm{Br}^{-}$in PBS and increasing $\mathrm{H}_{2} \mathrm{O}_{2}, \mathrm{pH} 7.4$ at $25^{\circ} \mathrm{C}$. The final reaction volume was $250 \mu \mathrm{L}$ and the microplate reader was set at 340/550. The results are the mean and $\mathrm{SD}$ of three experiments, $\mathrm{r}^{2}=0.9782, L O D=5.5 \mu \mathrm{M}$. C (c) Relationship between HOCl produced versus $\mathrm{H}_{2} \mathrm{O}_{2}$ added in the enzymatic reaction medium. 
dansylglycine was measured after $30 \mathrm{~min}$ of incubation at $37{ }^{\circ} \mathrm{C}$. Obviously, the lower reaction rate can be explained considering the necessity of initial formation of $\mathrm{HOCl}$ by the $\mathrm{MPO} / \mathrm{H}_{2} \mathrm{O}_{2}$ system. Our results also show that $10 \mathrm{mmol} \mathrm{L}^{-1}$ of $\mathrm{Br}^{-}$was enough to provoke the complete consumption of dansylglycine after $30 \mathrm{~min}$. From these results, it is reasonable to suppose that a relationship between the concentration of $\mathrm{H}_{2} \mathrm{O}_{2}$ and the fluorescence bleaching of dansylglycine should be also obtained by keeping constant the other components of the reaction. The results show in Fig. 4b confirmed our expectation, since a linear correlation was obtained for $\mathrm{H}_{2} \mathrm{O}_{2}$ versus $\Delta$ fluorescence. The detection limit for $\mathrm{H}_{2} \mathrm{O}_{2}$ was $5.5 \mathrm{mmol} \mathrm{L}^{-1}$. Finally, a linear correlation between the concentration of $\mathrm{H}_{2} \mathrm{O}_{2}$ and $\mathrm{HOCl}$ was also obtained (Fig. 4c). In these experiments, the equation obtained from the linear regression between the concentration of pure $\mathrm{HOCl}$ and $\Delta$ fluorescence of dansylglycine was used to calculate the production of $\mathrm{HOCl}$ by $\mathrm{MPO}$ as a function of $\mathrm{H}_{2} \mathrm{O}_{2}$. In short, these results show that in the presence of dansylglycine and $\mathrm{Br}^{-}$, the conversion of $\mathrm{H}_{2} \mathrm{O}_{2}$ to $\mathrm{HOCl}$ through catalytic action of MPO was quantitative and a stoichiometry of $1: 1$ $\left(\mathrm{H}_{2} \mathrm{O}_{2}: \mathrm{HOCl}\right)$ was obtained.

The dansylglycine assay was compared with the well-stablished and widely used assay based in the capture of $\mathrm{HOCl}$ by taurine
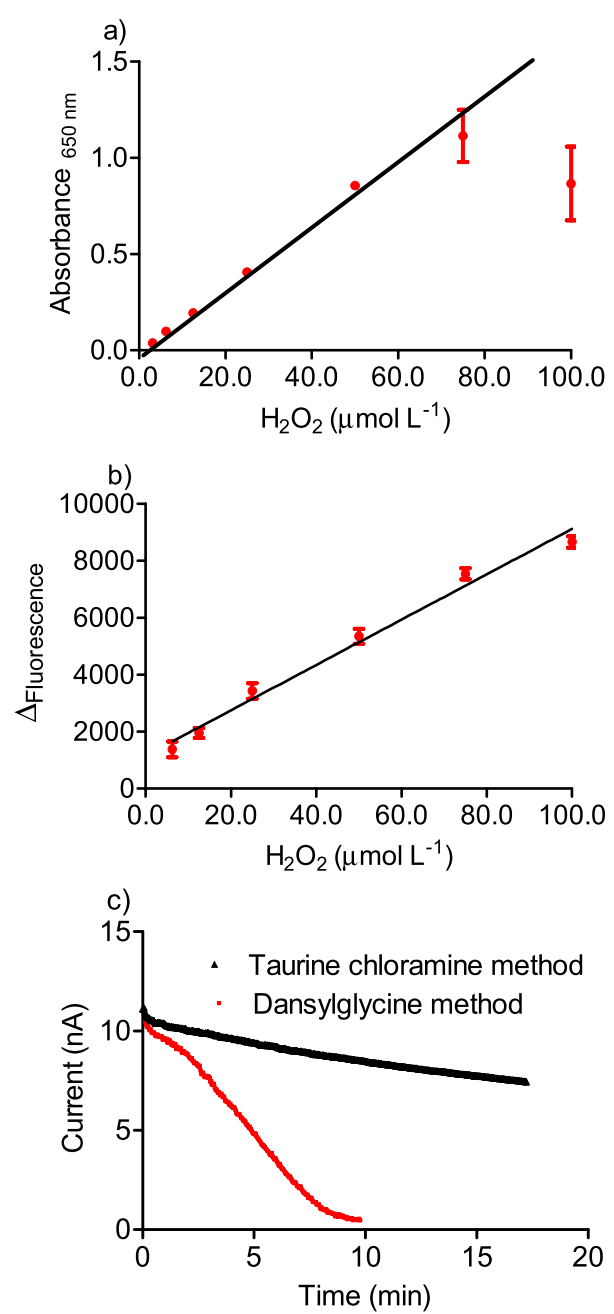

Fig. 5. Comparison of methodologies: Taurine/TMB versus dansylglycine. The reaction mixtures were composed of $5 \mathrm{nmol} \mathrm{L}^{-1} \mathrm{MPO}, \mathrm{H}_{2} \mathrm{O}_{2}$ in the range $0-100 \mu \mathrm{mol} \mathrm{L}^{-1}$ and (a) $10 \mathrm{mmol} \mathrm{L}^{-1}$ taurine or (b) $50 \mu \mathrm{mol} \mathrm{L}^{-1}$ dansylglycine in PBS, pH 7.4 at $25{ }^{\circ} \mathrm{C}$. The results are the mean and SD of three experiments. (c) Amperometric monitoring the consumption of $\mathrm{H}_{2} \mathrm{O}_{2}$ by selective electrode. leading to accumulation of taurine chloramine and its measurement by oxidation of the chromogenic substrate TMB [18]. The results depicted in Fig. 5a confirmed the efficacy of this methodology, but also showed that using only $5 \mathrm{nmol} \mathrm{L}^{-1} \mathrm{MPO}$, the enzyme seems to be partially inactivated, what could explain the lost of curve linearity above $70 \mu \mathrm{mol} \mathrm{L}^{-1} \mathrm{H}_{2} \mathrm{O}_{2}$. These results are not unexpected, since the denaturation of MPO by $\mathrm{H}_{2} \mathrm{O}_{2}$ is a welldocumented subject [35]. By comparing the results of the taurine/ TMB assay with those obtained using dansylglycine (Fig. 5a and b), we can conclude that the methodology in development was less susceptible to MPO degradation. An explanation for these findings is the high reactivity of $\mathrm{HOBr}$ with dansylglycine, which promotes a fast depletion of this oxidant avoiding the degradation of the enzyme. It addition, the second-order rate constant for the reaction between MPO-I and $\mathrm{Br}^{-}$leading to $\mathrm{HOBr}\left(1.1 \times 10^{6} \mathrm{~mol}^{-1} \mathrm{~L} \mathrm{~s}^{-1}\right)$ is significantly higher compared to $\mathrm{Cl}^{-}$leading to $\mathrm{HOCl}$ $\left(2.5 \times 10^{4} \mathrm{~mol}^{-1} \mathrm{~L} \mathrm{~s}^{-1}\right)$ [36]. Therefore, in the presence of $\mathrm{Br}^{-}$the depletion of $\mathrm{H}_{2} \mathrm{O}_{2}$ must be also faster causing less degradation of the enzyme. In opposition of that, taurine chloramine and $\mathrm{H}_{2} \mathrm{O}_{2}$ remain longer in contact with the enzyme before the revelation by adding TMB. Hence, it is reasonable to consider that it could be partially inactivated. To support this proposal, the efficient of the catalytic performance of MPO using dansylglycine was also compared to the taurine method by amperometric measurement of the consumption of $\mathrm{H}_{2} \mathrm{O}_{2}$ using a selective electrode. The results depicted in Fig. $5 \mathrm{c}$ show the efficiency of $\mathrm{H}_{2} \mathrm{O}_{2}$ consumption in both cases. Corroborant with the previous results, the consumption of $\mathrm{H}_{2} \mathrm{O}_{2}$ was significantly faster using dansylglycine $/ \mathrm{Br}^{-}$.

\section{Determination of MPO}

The above results led us to consider that the dansylglycine methodology could be also useful for determination of MPO activity. In this case, the concentration of $\mathrm{H}_{2} \mathrm{O}_{2}, \mathrm{Br}^{-}$and dansylglycine were fixed and the enzyme varied. The reaction rate was measured in the linear phase of the fluorescence versus time curve (Fig. 6a). The results in Fig. 6b confirmed our expectation and show that this methodology can be used for directly measurement of the halogenating activity of MPO. The detection limit of MPO was $6 \mathrm{nmol} \mathrm{L}^{-1}$. The excellent linearity obtained is an indication that the enzyme did not lose its activity, or at least, any loss that occurs is consistent under each enzyme concentration. Once more, the efficiency of the reaction was demonstrated.

\section{Selectivity for halogenation activity of MPO}

How stated above, we argued that this methodology could be selective regarding the discrimination between peroxidase and chlorinating activity of MPO. This hypothesis was tested by removing, one by one, the components of the reaction system. As expected, the consumption of dansylglycine was dependent of the presence of MPO and $\mathrm{H}_{2} \mathrm{O}_{2}$ (Table 1 ). In the same direction, the removal of $\mathrm{Br}^{-}$impaired the reaction. These results are in agreement with the higher electrophilicity of the $\mathrm{HOBr}$ compared to $\mathrm{HOCl}$, which is essential for reacting with dansylglycine. Finally, we replaced MPO by HRP and found that dansylglycine was not consumed, even though $\mathrm{Cl}^{-}$and $\mathrm{Br}^{-}$were present in the reaction medium. As well-known HRP is able to catalyze the oxidation of many substrates through its peroxidase cycle involving the correspondent active forms HRP-I and HRP-II. However, due to its low oxidation potential it is not able to oxidize halides [37]. Altogether, these results confirm the specificity of dansylglycine as a substrate for determination of the halogenating activity of MPO. 

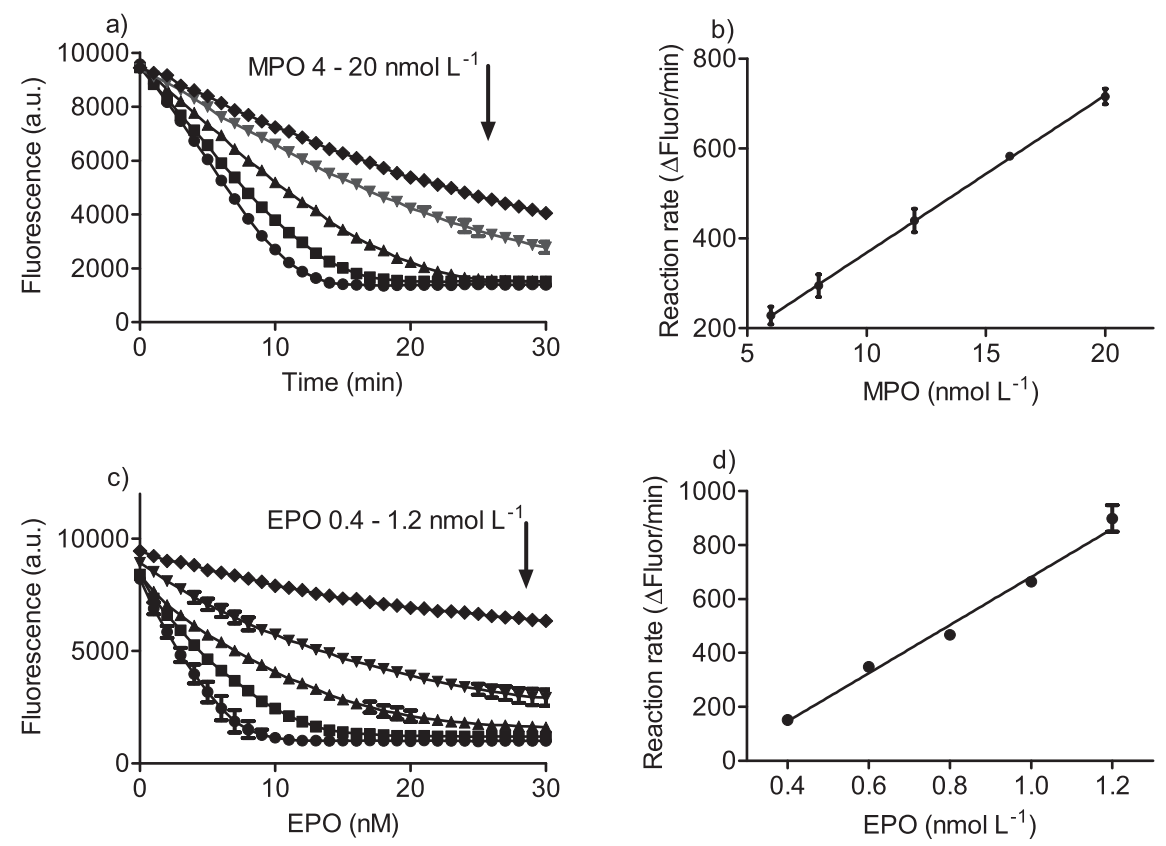

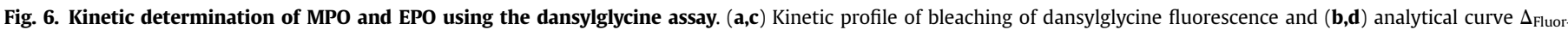

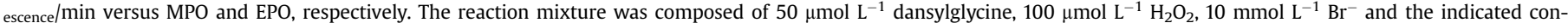

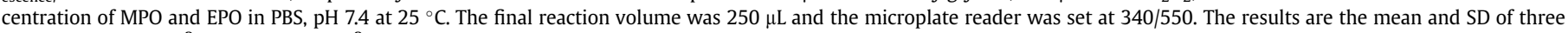
experiments. MPO $\left(r^{2}=0.9692\right)$, EPO $\left(r^{2}=0.9692\right)$.

Table 1

Dansylglycine assay: Specificity for halogenating activity of MPO.

\begin{tabular}{lll}
\hline & Dansylglycine consumption $\left.(\mu \mathrm{mol} \mathrm{L})^{-1}\right)$ & Dansylglycine consumption $(\%)$ \\
\hline Control $^{\mathrm{a}}$ & $45,9 \pm 0,7$ & $91,8 \pm 1,4$ \\
$-\mathrm{MPO}$ & $3.0 \pm 2.6$ & $6.0 \pm 5.2$ \\
$-\mathrm{H}_{2} \mathrm{O}_{2}$ & $3.8 \pm 2.6$ & $7.6 \pm 5.2$ \\
$-\mathrm{Br}^{-}$ & $2.9 \pm 2.2$ & $5.8 \pm 4.4$ \\
$\mathrm{HRP}^{\mathrm{b}}$ & $1.3 \pm 1.2$ & $2.6 \pm 2.4$ \\
\hline
\end{tabular}

Note. The results are presented as mean and standard deviation.

a Dansylglycine $50 \mu \mathrm{mol} \mathrm{L}{ }^{-1}$, MPO $20 \mathrm{nmol} \mathrm{L}^{-1}, \mathrm{Br}^{-} 10 \mathrm{mmol} \mathrm{L}^{-1}$ and $\mathrm{H}_{2} \mathrm{O}_{2} 100 \mu \mathrm{mol} \mathrm{L}^{-1}$ in $\mathrm{PBS}, \mathrm{pH} 7.4$ at $25^{\circ} \mathrm{C}$.

b MPO was replaced by HRP.

\section{Selectivity for halogenating activity of eosinophil peroxidase}

While MPO can oxidize both $\mathrm{Cl}^{-}$and $\mathrm{Br}^{-}$, EPO has much more affinity to $\mathrm{Br}^{-}$[38]. Therefore, as $\mathrm{Br}^{-}$is an important component of the dansylglycine assay, we also tested the methodology to measure $\mathrm{HOBr}$ produced by EPO. The results depicted in Fig. $6 \mathrm{c}$ show the excellent correlation between the EPO concentration and the fluorescence decay of dansylglycine. Moreover, the detection limit for EPO was higher compared to MPO, highlighting the efficiency by which $\mathrm{HOBr}$ is produced by the halogenating cycle of EPO and consumed by dansylglycine (Fig. 6d). These results can be explained taking into account that the reaction rate between EPO-I and $\mathrm{Br}^{-}$ $\left(1.0 \times 10^{7} \mathrm{~mol}^{-1} \mathrm{~L} \mathrm{~s}^{-1}\right)$ is 10 -fold higher compared to MPO-I and $\mathrm{Br}^{-}$ $\left(1.1 \times 10^{6} \mathrm{~mol}^{-1} \mathrm{~L} \mathrm{~s}^{-1}\right)$ at $\mathrm{pH} 7.0[36,39]$. The selectivity for halogenating activity using EPO was also verified (Table 2).

\section{Application of the dansylglycine assay for evaluation of inhibitors}

As stated in the introduction section, the numerous evidence of the involvement of MPO and EPO in the physiopathology of chronic and inflammatory diseases have led for a constant search for new inhibitors of these enzymes and evaluation of their potency $[14,15,40,41]$. Regarding the evaluation of the inhibitory potency of new compounds, the most used methods are the taurine chloramine assay and the use of $\mathrm{H}_{2} \mathrm{O}_{2}$-specific electrode [18,42]. The first one is highly specific for chlorination activity, however, it has the

Table 2

Dansylglycine assay: Specificity for halogenating activity of EPO.

\begin{tabular}{lll}
\hline & Dansylglycine consumption $\left(\mu \mathrm{mol} \mathrm{L}{ }^{-1}\right)$ & Dansylglycine consumption $(\%)$ \\
\hline Control $^{\mathrm{a}}$ & $47,3 \pm 0,1$ & $94.6 \pm 0.2$ \\
$-\mathrm{EPO}$ & $1.0 \pm 0.3$ & $2.0 \pm 0.6$ \\
$-\mathrm{H}_{2} \mathrm{O}_{2}$ & $1.4 \pm 1.0$ & $2.8 \pm 2.0$ \\
$-\mathrm{Br}^{-}$ & $1.1 \pm 0.4$ & $2.2 \pm 0.8$ \\
\hline
\end{tabular}

Note. The results are presented as mean and standard deviation.

${ }^{a}$ Dansylglycine $50 \mu \mathrm{mol} \mathrm{L}^{-1}$, EPO $20 \mathrm{nmol} \mathrm{L}^{-1}, \mathrm{Br}^{-} 10 \mathrm{mmol} \mathrm{L}^{-1}$ and $\mathrm{H}_{2} \mathrm{O}_{2} 100 \mu \mathrm{mol} \mathrm{L}^{-1}$ in PBS, pH 7.4 at $25^{\circ} \mathrm{C}$. 
drawback of being a two-step method, and therefore, it is not adequate kinetic monitoring the effect of the inhibitors in the chlorination rate. The use of $\mathrm{H}_{2} \mathrm{O}_{2}$-specific electrode allows the kinetic monitoring of the reaction, but is not selective for halogenating activity. Furthermore, the electrode is sensitive to interferences of the medium [18]. Here, we found that the dansylglycine assay, besides selective, is adequate for real-time measurement of the MPO/EPO activity. The results depicted in Fig. 7a and c shows the effect of 5-fluorotryptamine, a well-known and efficient reversible inhibitor of the halogenating activity of MPO [43], on the rate of dansylglycine fluorescence bleaching catalyzed by MPO and EPO, respectively. In this experiments a biphasic behavior was obtained, which can be explained considering the well-known effect of 5-fluorotryptamine on MPO, as follow: 5-Fluorotryptamine competes with $\mathrm{Cl}^{-}$by the redox active MPO-I leading to the inhibiting of $\mathrm{HOCl}$ production [43]. Then, once 5-fluorotryptamine is consumed, the production of $\mathrm{HOCl}$ can be reestablished. This property of 5-fluorotryptamine could explain the strong inhibition observed in the first minutes (lag phase) and, with the progress of the reaction and its depletion, the rate of consumption of dansylglycine almost returned to the initial condition. This kinetic behavior was still better observed using EPO (Fig. 7c). The lag phase was almost proportional to the concentration of 5-fluorotryptamine.

To reinforce the applicability of the dansylglycine method for elucidation of the mechanism of action of MPO and EPO inhibitors, we also tested the effect of 4-hydroxybenzhydrazide. This compound belongs to the benzoic acid hydrazide derivatives, which are potent and irreversible inhibitors of MPO [44]. The oxidation of hydrazides leads to free radical intermediates that destroy the heme group of MPO leading to its irreversible inactivation [44]. The results depicted in Fig. 8 show that, differently of 5fluorotryptamine, the inhibition provoked by 4hydroxybenzhydrazide did not present a biphasic behavior, i.e., without an initial lag phase. These results are consistent with the irreversible inhibitory character of this class of compounds. In
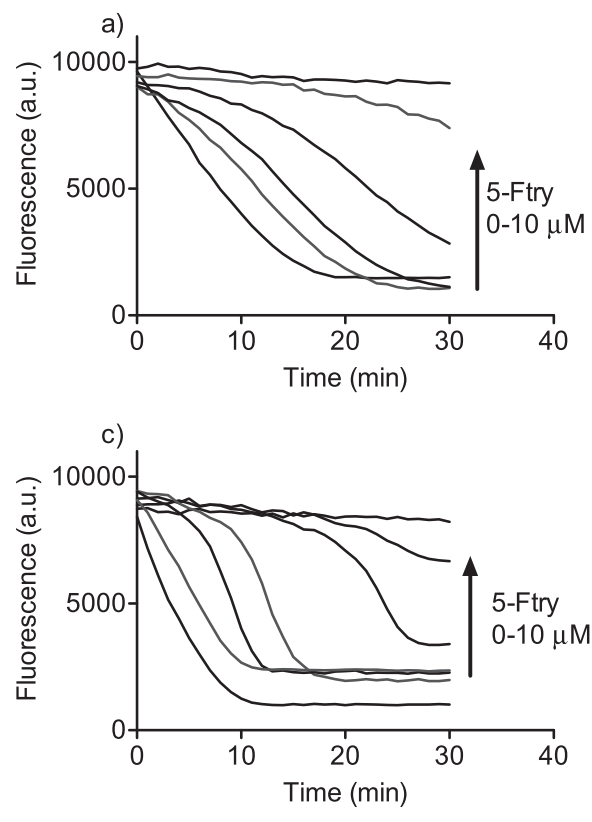

short, dansylglycine method could be useful to differentiate the mechanism of action of MPO/EPO inhibitors, i.e., reversible or irreversible. Finally, it is interesting to note that due to the higher stability of EPO compared to MPO, only $1.2 \mathrm{mmol} \mathrm{L}^{-1}$ was necessary to perform the kinetic studies. This is an additional advantage of this method, since purified EPO is the most expensive reagent for the screening of inhibitor for this enzyme.

\section{Discrimination between MPO and EPO}

The reactivity of MPO-I with $\mathrm{Cl}^{-}$leading to $\mathrm{HOCl}$ is $\mathrm{pH}$ dependent, being favored at acidic $\mathrm{pH}$ as indicated by its apparent second-order rate constants $3.9 \times 10^{6} \mathrm{~mol}^{-1} \mathrm{~L} \mathrm{~s}^{-1}$ and $2.5 \times 10^{4} \mathrm{~mol}^{-1} \mathrm{~L} \mathrm{~s}^{-1}$, at $\mathrm{pH} 5.0$ and 7.0 , respectively [36]. In addition, the reactivity of $\mathrm{HOCl}$ is increased in its protonated form $[45,46]$, the predominate species at pH 5.0 (pKa 7.44). For this reason, we hypothesized that by conducting the reaction at $\mathrm{pH} 5.0$, the dependence of $\mathrm{Br}^{-}$could be diminished or totally unnecessary. The results depicted in Fig. 9 show a comparison of the dansylglycine fluorescence bleaching at pH 5.0 and 7.4 in the absence of $\mathrm{Br}^{-}$and confirmed our expectation. EPO-I also follows the same $\mathrm{pH}$-dependence pattern, but its reactivity with $\mathrm{Cl}^{-}$is significantly lower compared to MPO-I, as can be noted by its apparent secondorder rate constants $2.6 \times 10^{4} \mathrm{~mol}^{-1} \mathrm{~L} \mathrm{~s}^{-1}$ and $3.1 \times 10^{3} \mathrm{~mol}^{-1} \mathrm{~L} \mathrm{~s}^{-1}$ at $\mathrm{pH} 5.0$ and 7,0, respectively [39]. In short, at $\mathrm{pH} 5.0$ and in the absence of $\mathrm{Br}^{-}$the difference between MPO and EPO reaches twoorder of magnitude. Therefore, we used these properties to discriminate MPO and EPO using the dansylglycine assay. Corroborant with our expectation, the conduction of the reaction without $\mathrm{Br}^{-}$at $\mathrm{pH} 5.0$ results in a clear difference between MPO and EPO (Fig. 9), and could be used as a kinetic assay for discrimination of the enzymes.

\section{Conclusions}

In summary, we have developed a non-expensive, one-step and
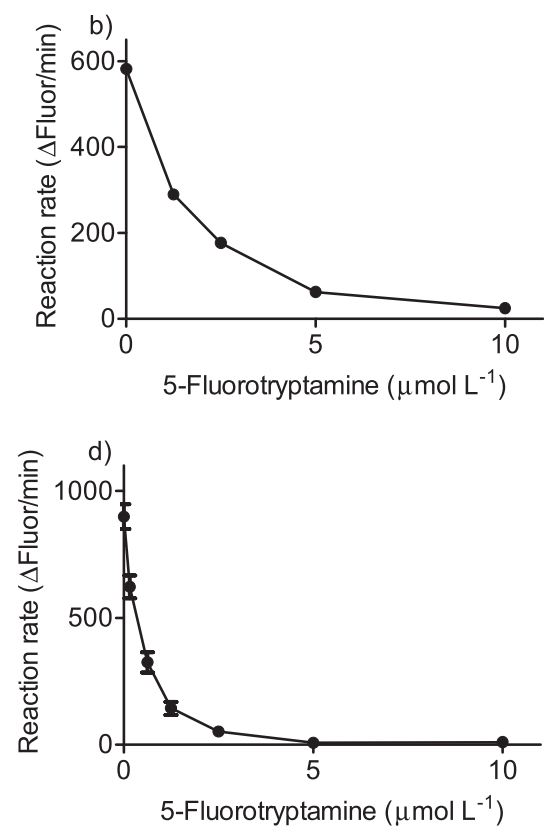

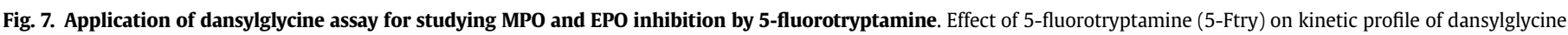

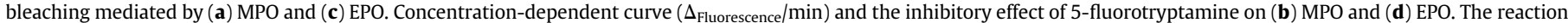

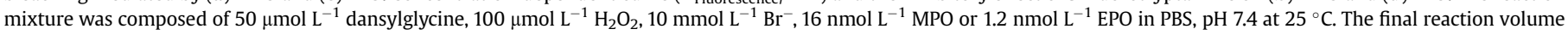
was $250 \mu \mathrm{L}$ and the microplate reader was set at 340/550. The results are the mean and SD of three experiments. 

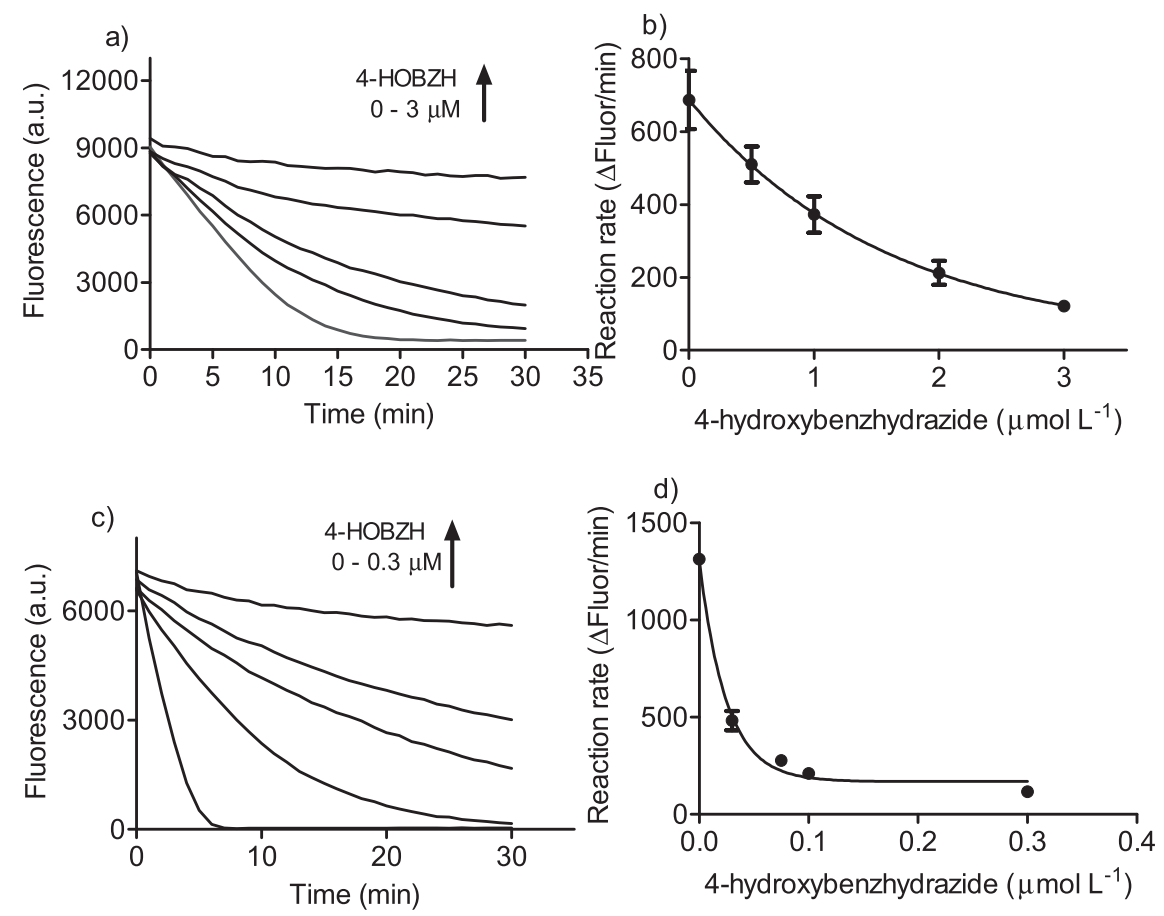

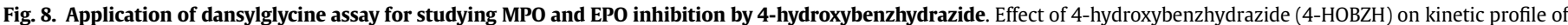

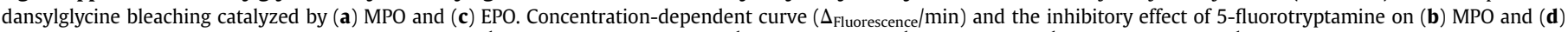

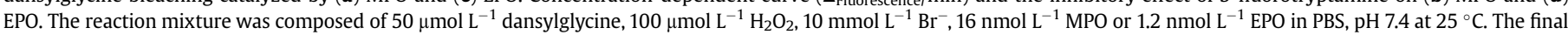
reaction volume was $250 \mu \mathrm{L}$ and the microplate reader was set at 340/550. The results are the mean and SD of three experiments.

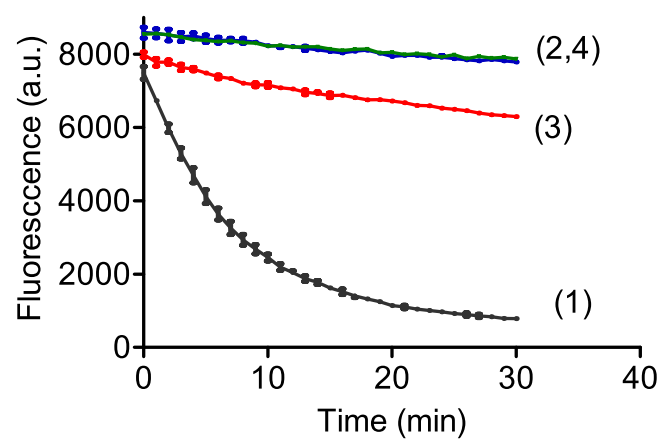

Fig. 9. Effect of $\mathrm{pH}$ on dansylglycine fluorescence bleaching in the absence of $\mathrm{Br}^{-}$. Discrimination between MPO and EPO. (1) MPO pH 5.0, (2) MPO pH 7.4, (3) EPO pH 5.0 and (4) EPO pH 7.4. The reaction mixture was composed of $50 \mu \mathrm{mol} \mathrm{L}^{-1}$ dansylglycine, $100 \mu \mathrm{mol} \mathrm{L}^{-1} \mathrm{H}_{2} \mathrm{O}_{2}$, MPO or EPO $\left(5 \mathrm{nmol} \mathrm{L}^{-1}\right)$ in PBS (pH 7.4) or $10 \mathrm{mmol} \mathrm{L}^{-1}$ phosphate buffer ( $\mathrm{pH} \mathrm{5.0)}$ at $25^{\circ} \mathrm{C}$. The final reaction volume was $250 \mu \mathrm{L}$ and the microplate reader was set at 340/550. The results are the mean and SD of three experiments.

selective procedure for analysis of the halogenating activity of MPO and EPO. We demonstrated that dansylglycine is a fluorescent probe susceptible to halogenating, but not to the peroxidase activity of MPO/EPO. The fluorescence bleaching of dansylglycine can be real-time monitored and correlated with the concentration of the enzyme. Therefore, the technique can be useful to study the efficiency and mechanism of action of potential inhibitors of these enzymes. The discrimination between MPO and EPO can be performed by altering the $\mathrm{pH}$ of the reaction mixture. Finally, the method may be of limited use in cases where endogenous compounds compete with dansylglycine for reaction with $\mathrm{HOBr}$. This, presumably, may be the case when measuring MPO and EPO activities in crude enzyme/tissue preparations. Hence, further studies must be performed to address these issues.

\section{Acknowledgments}

This work was supported by FAPESP (Fundação de Amparo à Pesquisa do Estado de São Paulo, grants 2015/21693-0 and 2016/ 20549-5), CNPq (Conselho Nacional de Desenvolvimento Científico e Tecnológico, grants 302793/2016-0 and 440503/2014-0).

\section{Appendix A. Supplementary data}

Supplementary data related to this article can be found at http:// dx.doi.org/10.1016/j.ab.2017.05.029.

\section{References}

[1] W.M. Nauseef, Myeloperoxidase in human neutrophil host defence, Cel Microbiol. 16 (2014) 1146-1155.

[2] D.C. Dale, L. Boxer, W.C. Liles, The phagocytes: neutrophils and monocytes, Blood 112 (2008) 935-945.

[3] G. Battistuzzi, M. Bellei, J. Vlasits, S. Banerjee, P.G. Furtmüller, M. Sola C. Obinger, Redox thermodynamics of lactoperoxidase and eosinophil peroxidase, Arch. Biochem. Biophys 494 (2010) 72-77.

[4] K.R. Acharya, S.J. Ackerman, Eosinophil granule proteins: form and function, J. Biol. Chem. 289 (2014) 17406-17415.

[5] P.G. Furtmüller, U. Burner, C. Obinger, Reaction of myeloperoxidase compound I with chloride, bromide, iodide, and thiocyanate, Biochemistry 37 (1998) $17923-17930$.

[6] W. Adam, M. Lazarus, C.R. Saha-Moller, et al., Biotransformations with peroxidases, in: T. Sheper (Ed.), Advanced in Biochemical Engineering/Biotechnology, Springer-Verlag, Berlin, Germany, 1999, pp. 73-108.

[7] L.G. Fenoll, F. García-Molina, M.A. Gilabert, R. Varón, P.A. García-Ruiz, J. Tudela, F. García-Cánovas, J.N. Rodríguez-López, Interpretation of the reactivity of peroxidase compound II with phenols and anilines using the Marcus equation, Biol. Chem. 386 (2005) 351-360.

[8] S.J. Klebanoff, A.J. Kettle, H. Rosen, C.C. Winterbourn, W.M. Nauseef, Myeloperoxidase: a front-line defender against phagocytosed microorganisms, J. Leukoc. Biol. 93 (2013) 185-198.

[9] S. Souparnika, B. D'Souza, V. D'Souza, S. Kumar, P. Manjrekar, M. Bairy, R. Parthasarathy, S. Kosuru, Emerging role of myeloperoxidase in the prognosis of nephrotic syndrome patients before and after steroid therapy, J. Clin. Diagn. Res. 9 (2015) 1-4. 
[10] P. Teismann, Myeloperoxidase in the neurodegenerative process of Parkinson's disease, Dtsch. Med. Wochenschr 139 (2014) 99-102.

[11] A. Cabassi, S.M. Binno, S. Tedeschi, G. Graiani, C. Galizia, M. Bianconcini, P. Coghi, F. Fellini, L. Ruffini, P. Govoni, M. Piepoli, S. Perlini, G. Regolisti E. Fiaccadori, Myeloperoxidase-related chlorination activity is positively associated with circulating ceruloplasmin in chronic heart failure patients: relationship with neurohormonal, inflammatory, and nutritional parameters, Biomed. Res. Int (2015) 691693.

[12] M.A. Rank, S.I. Ochkur, J.C. Lewis, H.G. Teaford, L.J. Wesselius, R.A. Helmers, N.A. Lee, P. Nair, J.J. Lee, Nasal and pharyngeal eosinophil peroxidase levels in adults with poorly controlled asthma correlate with sputum eosinophilia, Allergy 71 (2016) 567-570.

[13] B.S. Rayner, D.T Love, C.L. Hawkins, Comparative reactivity of myeloperoxidase-derived oxidants with mammalian cells, Free Radic. Biol. Med 71 (2014) 240-255.

[14] R.B. Ruggeri, L. Buckbinder, S.W. Bagley, P.A. Carpino, E.L. Conn, M.S. Dowling D.P. Fernando, W. Jiao, D.W. Kung, S.T. Orr, Y. Qi, B.N. Rocke, A. Smith, J.S. Warmus, Y. Zhang, D. Bowles, D.W. Widlicka, H. Eng, T. Ryder, R. Sharma, A. Wolford, C. Okerberg, K. Walters, T.S. Maurer, Y. Zhang, P.D. Bonin, S.N. Spath, G. Xing, D. Hepworth, K. Ahn, A.S. Kalgutkar, Discovery of 2-(6-(5Chloro-2-methoxyphenyl)-4-oxo-2-thioxo-3,4-dihydropyrimidin-1(2H)-yl) acetamide (PF-06282999): a highly selective mechanism-based myeloperoxidase inhibitor for the treatment of cardiovascular diseases, J. Med. Chem. 58 (2015) 8513-8528.

[15] L.V. Forbes, T. Sjögren, F. Auchère, D.W. Jenkins, B. Thong, D. Laughton, P. Hemsley, G. Pairaudeau, R. Turner, H. Eriksson, J.F. Unitt, A.J. Kettle, Potent reversible inhibition of myeloperoxidase by aromatic hydroxamates, J. Biol. Chem. 288 (2013) 36636-36647.

[16] A.J. Kettle, C.C. Winterbourn, The mechanism of myeloperoxidase-dependent chlorination of monochlorodimedon, Biochim. Biophys. Acta 957 (1988) $185-191$.

[17] A.J. Kettle, C.C. Winterbourn, Assays for the chlorination activity of myeloperoxidase, Methods Enzymol 233 (1994), 502-152.

[18] A.J. Kettle, A.M. Albrett, A.L. Chapman, N. Dickerhof, L.V. Forbes, I. Khalilova, R. Turner, Measuring chlorine bleach in biology and medicine, Biochim. Biophys. Acta 1840 (2014) 781-793.

[19] K. Setsukinai, Y. Urano, K. Kakinuma, H.J. Majima, T. Nagano, Development of novel fluorescence probes that can reliably detect reactive oxygen species and distinguish specific species, J. Biol. Chem. 278 (2003) 3170-3175.

[20] J. Flemmig, J. Remmler, J. Zschaler, J. Arnhold, Detection of the halogenating activity of heme peroxidases in leukocytes by aminophenyl fluorescein, Free Radic. Res. 49 (2015) 768-776

[21] J. Flemmig, J. Zschaler, J. Remmler, J. Arnhold, The fluorescein-derived dye aminophenyl fluorescein is a suitable tool to detect hypobromous aci (HOBr)-producing activity in eosinophils, J. Biol. Chem. 287 (2012) 27913-27923.

[22] L. Yuan, W. Lin, Y. Xie, B. Chen, J. Song, Fluorescent detection of hypochlorous acid from turn-on to FRET-based ratiometry by a $\mathrm{HOCl}$-mediated cyclization reaction, Chemistry 18 (2012) 2700-2706.

[23] L.A. Marquez, J.T. Huang, H.B. Dunford, Spectral and kinetic studies on the formation of myeloperoxidase compound I and II: roles of hydrogen peroxide and superoxide, Biochemistry 33 (1995) 1447-1454.

[24] B.G.J.N. Bolscher, H. Plat, R. Wever, Some properties of eosinophil peroxidase, a comparison with other peroxidases, Biochim. Biophys. Acta 784 (1984) $177-186$.

[25] R.J. Beers, I.W. Sizer, Spectrophotometric method for measuring the breakdown of hydrogen peroxide by catalase, J. Biol. Chem. 195 (1952) 133-140.

[26] J.C. Morris, The acid ionization constant of $\mathrm{HClO}$ from 5 to 35, J. Phys. Chem.
70 (1966) 3798-3805.

[27] M.S. Petronio, V.F. Ximenes, Effects of oxidation of lysozyme by hypohalous acids and haloamines on enzymatic activity and aggregation, Biochim. Biophys. Acta 1824 (2012) 1090-1096.

[28] V.F. Ximenes, S.O. Silva, M.R. Rodrigues, L.H. Catalani, G.J. Maghzal, A.J. Kettle, A. Campa, Superoxide-dependent oxidation of melatonin by myeloperoxidase, J. Biol. Chem. 280 (2005) 38160-38169.

[29] V.F. Ximenes, F.S. Graciani, Investigation of human albumin-induced circular dichroism in dansylglycine, PLoS One 8 (2013) e76849.

[30] V.F. Ximenes, N.H. Morgon, A.R. de Souza, Hypobromous acid, a powerful endogenous electrophile: experimental and theoretical studies, J. Inorg. Biochem. 146 (2015) 61-68.

[31] O. Augusto, S. Miyamoto, K. Pantopoulos, H.M. Schipper (Eds.), Principles of Free Radical Biomedicine, Nova Science Publishers Inc., New York (, 2011, pp. $1-23$.

[32] D. Maitra, I. Abdulhamid, M.P. Diamond, G.M. Saed, H.M. Abu-Soud, Melatonin attenuates hypochlorous acid-mediated heme destruction, free iron release, and protein aggregation in hemoglobin, J. Pineal Res. 53 (2012) 198-205.

[33] R.F. Queiroz, S.M. Vaz, O. Augusto, Inhibition of the chlorinating activity of myeloperoxidase by tempol: revisiting the kinetics and mechanisms, Biochem. J. 439 (2011) 423-431.

[34] V.F. Ximenes, I.M. Paino, O.M. Faria-Oliveira, L.M. Fonseca, I.L. Brunetti, Indole ring oxidation by activated leukocytes prevents the production of hypochlorous acid, Braz. J. Med. Biol. Res. 38 (2005) 1575-1583.

[35] M. Paumann-Page, P.G. Furtmüller, S. Hofbauer, L.N. Paton, C. Obinger, A.J. Kettle, Inactivation of human myeloperoxidase by hydrogen peroxide, Arch. Biochem. Biophys 539 (2013) 51-62.

[36] P.G. Furtmüller, U. Burner, C. Obinger, Reaction of myeloperoxidase compound I with chloride, bromide, iodide, and thiocyanate, Biochemistry 37 (1998) 17923-17930.

[37] M. Morrison, G.R. Schonbaum, Peroxidase-catalyzed halogenation, Annu. Rev. Biochem. 45 (1976) 861-888.

[38] J. Arnhold, E. Monzani, P.G. Furtmüller, M. Zederbauer, L. Casella, C. Obinger, Kinetics and thermodynamics of halide and nitrite oxidation by mammalian heme peroxidases, Eur. J. Inorg. Chem. (2006) 3801-3811.

[39] P.G. Furtmüller, U. Burner, G. Regelsberger, C. Obinger, Spectral and Kinetic Studies on the formation of eosinophil peroxidase compound I and its reaction with halides and thiocyanate, Biochemistry 39 (2000) 15578-15584.

[40] T. Lazarević-Pasti, A. Leskovac, V. Vasić, Myeloperoxidase inhibitors as potential drugs, Curr. Drug Metab 16 (2015) 168-190.

[41] P. Van Antwerpen, K. Zouaoui Boudjeltia, Rational drug design applied to myeloperoxidase inhibition, Free Radic. Res. 49 (2015) 711-720.

[42] A.J. Kettle, C.C. Winterbourn, Assays for the chlorination activity of myeloperoxidase, Methods Enzymol 233 (1994) 502-512.

[43] J. Soubhye, M. Prévost, P. Van Antwerpen, K. Zouaoui Boudjeltia, A. Rousseau, P.G. Furtmüller, C. Obinger, M. Vanhaeverbeek, J. Ducobu, J. Néve, M. Gelbcke, F.O. Dufrasne, Structure-based design, synthesis, and pharmacological evaluation of 3-(aminoalkyl)-5-fluoroindoles as myeloperoxidase inhibitors, J. Med. Chem. 53 (2010) 8747-8759.

[44] A.J. Kettle, C.A. Gedye, M.B. Hampton, C.C. Winterbourn, Inhibition of myeloperoxidase by benzoic acid hydrazides, Biochem. J. 308 (1995) 559-563.

[45] S. Wybraniec, K. Starzak, Z. Pietrzkowsk, Chlorination of betacyanins in several hypochlorous acid systems, J. Agric. Food Chem. 64 (2016) 2865-2874.

[46] D.R. Ramos, M.V. García, L.M. Canle, J.A. Santaballa, P.G. Furtmüller, C. Obinger, Myeloperoxidase-catalyzed chlorination: the quest for the active species, J. Inorg. Biochem. 102 (2008) 1300-1311. 